\title{
RAPID THERMAL PROCESSING OF HIGH-EFFICIENCY SILICON SOLAR CELLS WITH CONTROLLED IN-SITU ANNEALING
}

\author{
P. Dosh'', A. Rohatgi', M. Ropp', Z. Chen', D. Ruby', D. L. Meier" \\ 'University Center of Excellence for Photovoltaics Research and Education, Georgia Institute of Technolosy, Aulanta, GA 30332 \\ ${ }^{2}$ Sandia National Laboratories, M.S. 0752, Albuquerque, MM 87185 \\ TEBARA Solar, Inc., 811 Ri 51 South, Large, PA 15025
}

\begin{abstract}
Silicon solar cell efficiencies of $17.1 \%, 16.4 \%$, $14.8 \%$, and $14.9 \%$ have been achieved on $\mathrm{FZ}, \mathrm{Cz}$, multierystalline (mc-Si), and dendritic web (DW) silicon, respectively, using simplified, cost-effoctive rapid thermal processing (RIP). These represent the tighest reported efficiencies for solar cells processed with simultaneous front and beck diffusion with no conventional high-temperature furnace steps. Appropriate diffusion temperature coupled with the added in-sin anneal resulted in suitable minority-carrier lifetime and diffusion profiles for highefticiency cells. The cooling rate associated with the in-sin anneal can improve the lifetime and lowrer the reverse saruration current density $\left(J_{0}\right)$, however, this effect is material and base resistivity specific. PECVD antireflection (AR) coatings provided low reflectance and efficient front surface and bulk defect passivation. Conventional cells fabricated on $\mathrm{FZ}$ silicon by furnace diffusions and oxidations gave an efficiency of $18.8 \%$ due to greater short wavelength respanse and lower $\mathrm{J}_{0}$.
\end{abstract}

\section{INTRODUCTION}

Low-cost and high efficiency are the keys to largescale acceptability of phocovolraic (PV) systems. PV modules today cost about $\$ 4 / W a t h$, which can produce clectricity at a rate of about $25 \mathrm{k} / \mathrm{kWh}$. A factar of two in cost reduction is needed to make PV attractive for peak load applications and ahout a factor of 3 or 4 reduction would make it extremely competitive with conventional energy sources for base load utility applications. No PV material or technology has yet been able to achieve the cost and efficiency goals simultaneoussly because the efficient calls are too expensive and the cheaper cells are not efficient enough. Rapid thermal processing directly oddresses the issue of fabrication cost by significantly redueing the cell process time, thermal budget, and wafer clearing steps, without a significant loss in cell efficiency. RTP cell fabrication in this study involves a rapid, simultaneous front and back diffision for the formation of an etnitrer and back-suriace-field, followed by a rapid lowtemperanure $\mathrm{PECVD}$ of $\mathrm{SiN} / \mathrm{SiO}$, coating for efficient front surface passivation and AR costing [1]. Conventional fumace processing (CFP) generally involves separate fumsce diffusions and oxidations at high temperatures, which require extensive wafer cleaning, prolonged cell processing, and use more chernicals and geses.

Various investigators [2-8] have anempted RTP techniques in the past for silicon soler cell fabrication with only maderate success. Until recently, RTP tochniques involving simultaneous front and back diffusions, using tungsten-halogen lamps, have resulted in cell efficiencies in the range of 12 $15.4 \%[2-8]$ on single and multicrystalline silicon (Fig. I).

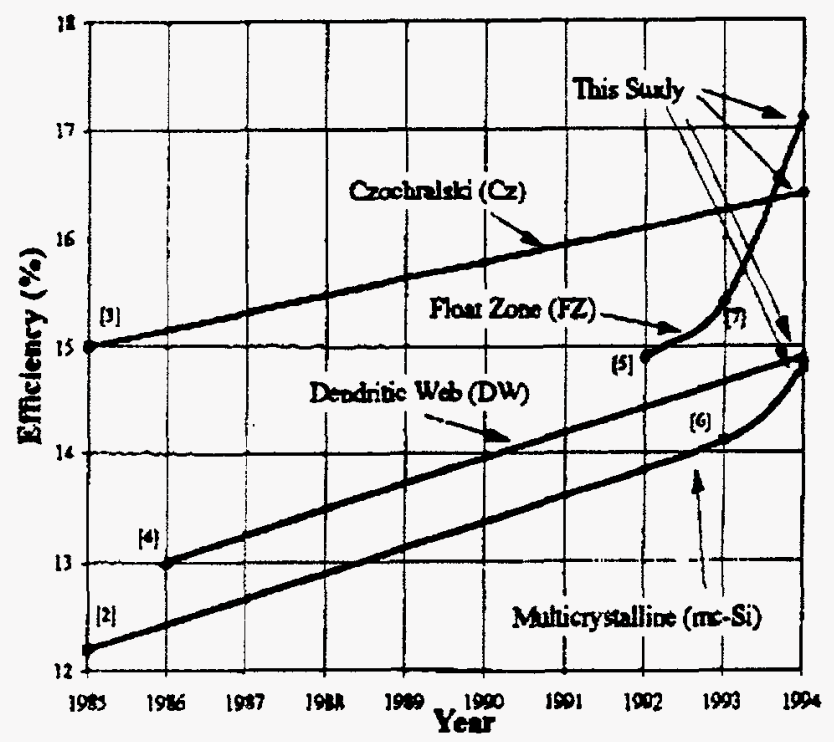

Fig. 1. Progress of RTP-diffused silicon solar colls without any furnace tramem. (The number is brekess represents the reference.)

Lower RTP cell efficiency is predominantly due to inappropriate diffusion profiles and lifetime degradation by rapid cooling rates and high quench temperatures, as will be discussed later.

Campbell and Meier [4] antempted to revive the lifetime of rapidly-cooled cells by performing post-RTP furnace anneals at high temperetures. They succeeded in raising the efficiency of n-type, $2 \Omega-\mathrm{cm}$, DW $\alpha$ ells from $13 \%$ to $15.2 \%$ with the anrical. This anneal, however, mitigates the attractiveness of RTP since it requires a lang furnace step.

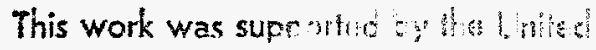

States Deparment a linerty thits?

Contract DE-AC 4. 9.4. 5000 \%

MASTER 


\section{DISCLAIMER}

This report was prepared as an account of work sponsored by an agency of the United States Government. Neither the United States Government nor any agency thereof, nor any of their employees, makes any warranty, express or implied, or assumes any legal liability or responsibility for the accuracy, completeness, or usefulness of any information, apparatus, product, or process disclosed, or represents that its use would not infringe privately owned rights. Reference herein to any specific commercial product, process, or service by trade name, trademark, manufacturer, or otherwise does not necessarily constitute or imply its endorsement, recommendation, or favoring by the United States Government or any agency thereof. The views and opinions of authors expressed herein do not necessarily state or reflect those of the United States Government or any agency thereof. 


\section{DISCLAIMER}

Portions of this document may be illegible in electronic image products. Images are produced from the best available original document. 
Schind]et et al. [7], fabricated $115.4 \%$ eftrcient cell on $1 \Omega$-em FZ without a post-RTP furance anneal. RTP dillusion al $1000^{\circ} \mathrm{C}$ with a cooling rate of $50^{\circ} \mathrm{C} / \mathrm{sec}$ can lead to plastic deformation via excessive thermal stress [9] and lifetirne degradation due to quenching. In addition. the high diffusion temperature resulted in a low emitter sheet resistance of $28 \Omega / \square$ which is accompenied by a thick dead layer and reduction in shor wavelength response due to Auger recombination and bandgap narrowing. High eminer-surface concentration also contributes to poor front-surface passivation.

Recently, we reported $16.9 \%$ efficient RTP cells on F2 silicon [10]. In this study, the diffusion temperature and cooling rates were controlled to schieve the bes RTP cell efficiemcies to clate on $\mathrm{FZ}, \mathrm{Cz}, \mathrm{mc}-\mathrm{Si}$, and $\mathrm{DW}$ silicon, without any pre or post-RTP furnace anneal.

\section{FABRICATION OF RTPAECVD SOLAR CELLS}

The fabrication of RTP/PECVD cells was recently published in ref. [10]. These cells are fabricated withoul any furnace anneals. Instead, shor in-sim lamp anneal is incorporated for lifetime recovery, appropriate junction depth. and suitable sheet resistance. Simple $n^{+}-p_{-}^{+}$cells are fabricated by 4 shot and simultaneous RTP diffusion of spin-on phosphorus dopants on the front and evaporated aluminum on the back, followed by a 9 min deposition of SiN/SiO $A R$ coatings by PECVD.

A number of experiments were performed to select the RIP thermal cycle (Fig, 2). Each segment of the thermal

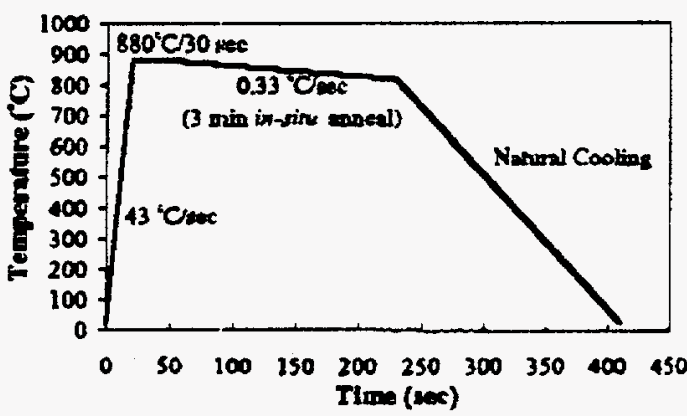

Fig. 2. Programmed thermal cycle for RTP simulassous difition

cycle is important. For example, the $880^{\circ} \mathrm{C} / 30 \mathrm{sec}$ peakiemperature step determines the surface concentration, $\mathrm{J}_{0}$, and sheet resistance, similariy, the slow cooling rate of $0.33^{\circ} \mathrm{C} / \mathrm{sec}$ for $3 \mathrm{~min}$ allows the formation of an Al beck-surface-field, performs Al gettering [11\}, prevents lifetime degradation due to rapid quenching from high temperatures, and creates appropriate junction depths and diffusion proflles for highefficiency cells. The $880^{\circ} \mathrm{C}$ processing temperature falls within the optimum renge of $850^{\circ} \mathrm{C}-900^{\circ} \mathrm{C}$ [12] for RTP phosphorus gettering and is sufficiently low to prevent slip dislocations, which may emerge at cemperatures $>1000^{\circ} \mathrm{C}[9]$. The $30 \mathrm{sec}$ time at peak-temperature also allows sufficient time for the partial lifetime "recovery" phenomenon [13] to occur. PECVD $\mathrm{SiN} / \mathrm{SiO}_{2}$ coatings provide good surface passivation, very efficient, double-layer AR properies, and passivation of grown- in or process-indised bulk defects in silicon. Thus, the combination of appropriate RTP sequence and PECVD coatings allows control of key material and device parameters necessary to fabricate high efliciency cells. Additionally, it reduces the thermal budget, relexes the wafer cleaning requirements. reduces the use of chemicals and gases, and increases the yield. In addition, there is the polential for high throughput because RTP systems are well suited for continuous wafer hearing by conveyor belis [7]

\section{RESULTS AND DISCUSSION}

\section{Comparison Between RTP and CFP Cells}

Table I summarizes the cell parameters along with the highest RIP cell efficiencies achieved on $\mathrm{FZ}, \mathrm{Cz}, \mathrm{mc}-\mathrm{Si}$, and DW silicon. Fig. 3 illustrates the front and back diffusion

Table 1. High-eficiency RTP/PECVD Si solur cells. All celle bave been mesured at Sundia Nutional Labs (SNL).

\begin{tabular}{|c|c|c|c|c|}
\hline Matertal & $V_{\alpha}(m v)$ & $J_{c}(m A)$ & $\mathbf{F F}$ & En $(\%)$ \\
\hline$F Z(0.2 \Omega-\mathrm{cm})$ & 637 & 32.8 & 0.819 & 17.1 \\
\hline$C_{2}(0.8 \Omega(\mathrm{cm})$ & 609 & 35.2 & 0.763 & 16.4 \\
\hline $\mathrm{mc}-\mathrm{Si}(0.8 \Omega \mathrm{cm})$ & 594 & 33.0 & 0.756 & 14.8 \\
\hline DW $(11 \Omega \mathrm{cm})$ & 559 & 34.5 & 0.771 & 14.9 \\
\hline
\end{tabular}

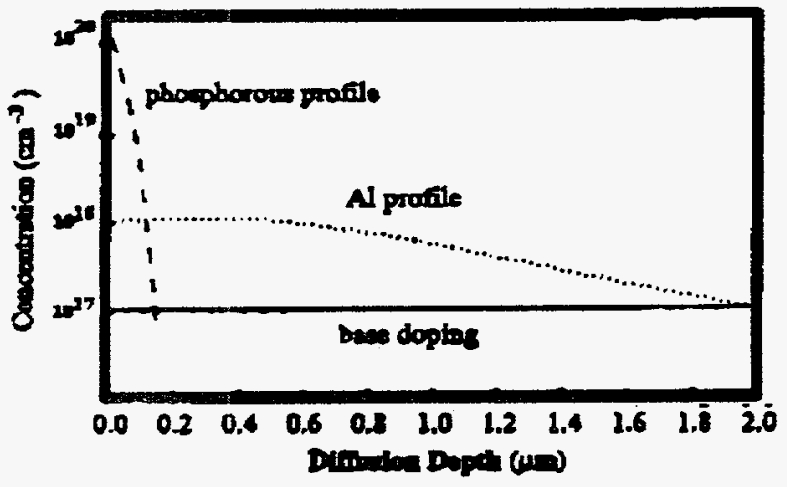

Fig. 3. Front and back diffusion profiles simulaneously diffused during the RIP treauners in fig. 2. (Measured on $0.2 \Omega \mathrm{am} F Z$ ample.)

profiles obtained by the $7 \mathrm{~min}$. time/temperature cycle in fig. 2 . Phosphonus eminet profiles, measured by spreading resisunce, had surface concentration about $2 \times 10^{20} \mathrm{~cm}^{-3}$ and a junction depth of $0.15 \mathrm{\mu m}$. This resulted in a sheet resjistance of 80 $\Omega O$. The aluminum back-surface-field profilc, determined by C.V measurements using an electrochemical etching profiler, had a surface concentration of $10^{12} \mathrm{~cm}^{3}$ and a junction depth of $2 \mathrm{\mu m}$. These simultaneously diffused profiles are quire consistent with the requirements for high-efficiency silicon cells and can be optimized further for even better results. Fig. 4 shous the internal quantum efficiency (IQE) of a typical $16.9 \%$-efficien RTPIPECVD cell. The IQE analysis gave a bulk diffusion length $\left(L_{d}\right)$ of $212 \mu \mathrm{m}$ corresponding 10 a bulk lifetime ( 3 ) of about $22 \mu \mathrm{s}$ in the $0.2 \Omega \mathrm{cm}$ bace.

Fig. 4 also shows a comparison of the IQE between 


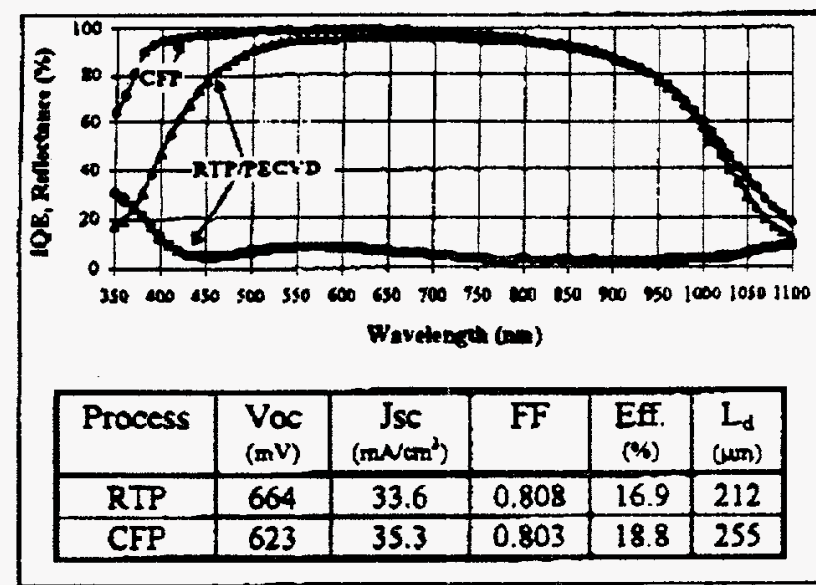

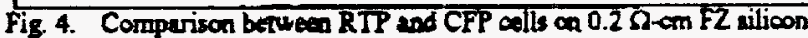

typical CFP and RTP diffused cells on $0.2 \Omega \mathrm{cm}$ FZ Si. CFP cell fabrication involved $930^{\circ} \mathrm{C} / 25 \mathrm{~min}$ phosphorus diffusion on the front, followed by an etch back to obtain a comparable emitrer sheet resistance of $80 \Omega / D$, and $850^{\circ} \mathrm{C} / 45 \mathrm{~min} \mathrm{Al}$ diffusion on the back which includes a $10 \mathrm{~min}$ thermal oxide passivation on the front. The conventional cell gave an efficiency of $18.8 \%$ with a slightly better long wavelength response but considerably better shon wavelength response indicating somewhat bigher bulk diffision length $(255 \mu \mathrm{m})$ and much lower front surface recombination velocity (FSRV). Emitter doping profile measurements for the conveational cell showed a much lower surface concentration of $2 \times 10^{19} \mathrm{~cm}^{-3}$ and 8 junction depth of $0.6 \mu \mathrm{m}$. The order of magnitude higher surface cancentration of the RIP emitte can increase FSRV, Auger recombination, and bandgap narrowing to account for the poor short wavelength response. Restarch is underway to increase the short and long wavelength response of the RTPIPECVD cells by optimizing the $\mathrm{J}_{\infty}$ vis eminer etch-back [14] and by improving of values to bridge the gap berween the conventional and RIP cells. The RIP cell efficiencies in excess of $17 \%$ achieved in this study demonstrate the potential for low-cost, bigh-efficiency RIP cells. To improve the efficiencies further, a better understanding of the effects of the RTP cooling rates associated with the in-sisu anneal is needed.

\section{Effects of RTP Coollog Rate on $\tau_{m} J_{m}$ and Emciency}

Several researchers have attributed many of the problems associated with RIP to quenching-induced recombination centers particularly introduced by activation of residual metallic impurities $[15,16]$. Rohatgi et al. [17], have shoun that, during CFP, sapid cooling rates and high quench temperatures can freeze grown-in or process-induced impurities into electrically active sites or decorate defects to make them more detrimental. Several researchers [13,15] have shown significant diffusion length degradation with the increase of RIP quench temperature. In this paper, the problems associared with rapid cooling rates during RTP are investigated in detail by using four different cooling rates (Fig. S) between the temperatures of $880^{\circ} \mathrm{C}$ and $820^{\circ} \mathrm{C}$ : $0.1^{\circ} \mathrm{C} / \mathrm{sec}$ which involves a $10 \mathrm{~min}$ in-sis anneal, $0.33^{\circ} \mathrm{C} / \mathrm{sec}$ which involves a $3 \mathrm{~min}$ in-situ amnenl, $1^{\circ} \mathrm{C} / \mathrm{sec}$ which involves a 1 min in-situ annesl, and $50^{\circ} \mathrm{C} / \mathrm{sec}$ which involves no annealing (Quenched).

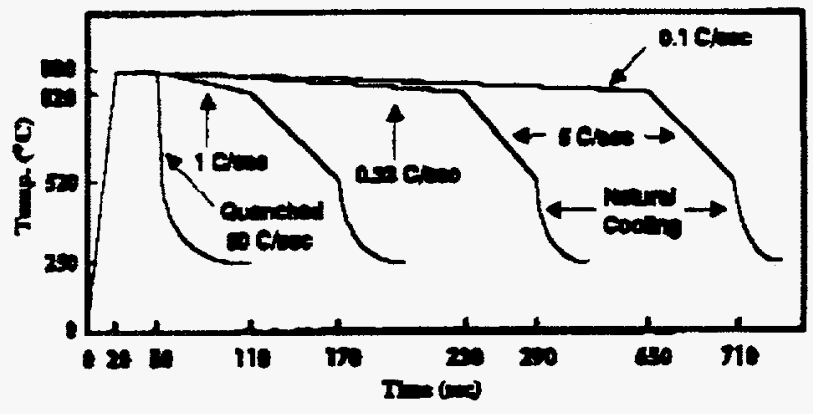

Fig. 5. Temperalue cyeles for RTP cooling rate experiments.

Preliminary experiments on $\mathrm{FZ}$ silicon involving $880^{\circ} \mathrm{C}$ peak temperatures exhibited no major quenching problems below $820^{\circ} \mathrm{C}$.

First, high-resistivity, high-lifetime FZ silican wafers were used to investigate the effects of RTP cooling rate on $z_{b}$. Fig. 6 establishes, for the first time, trend in the cooling rate induced lifetime degradation for an RIP system. In this experiment, sample preparation mimicked cell fabrication including the emitter formation steps in order to manifest any RTP induced P-gettering. Prior to the measurements, the emitters were etched allay and it was measured by the photoconductive decay technique with the sumples immersed in HFF. Quenching from $880^{\circ} \mathrm{C}$ resulited in a poor to of only 180 $\mu 5$, however, slow cooling at a rate of $0.1^{\circ} \mathrm{C} / \mathrm{sec}$ gives very high lifetines above $1.8 \mathrm{~ms}$ on tigh-resistivity $\mathrm{FZ} \mathrm{Si}$. Such high to values demonstrate that RIP techniques are capable of achieving lifetimes compatible with very high-efficiency solar cells.

The effect of some of these cooling rates on PV devices fabricated fom the same DW crystal is shown in fig. 7.

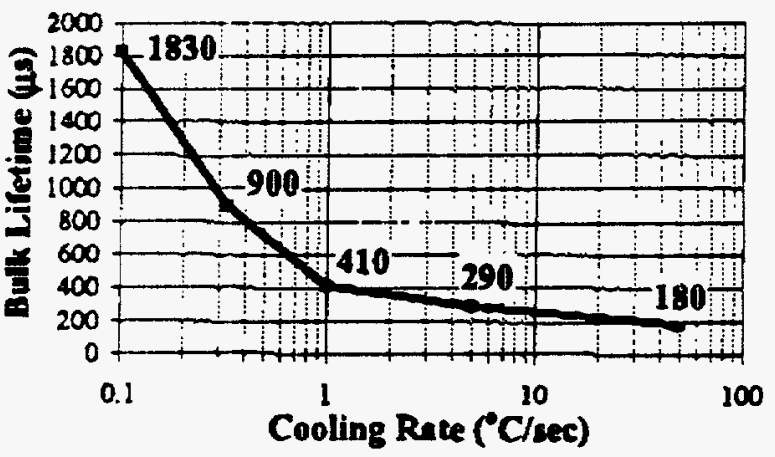

Fig 6. Efrea of RTP cooling rate on the bull lifetime of high resistivity ( $500-1000$ $\Omega$-m) FZ ailicon. (Penk iemperacure $=830^{\circ} \mathrm{C}$ )

The DW cells exhibit a strong dependence on RTP cooling rates. Quenching resulted in only a $10.2 \%$ efficient DW cell:; however, it irnproved to $14.9 \%$ when slow-cooled at a rate of 


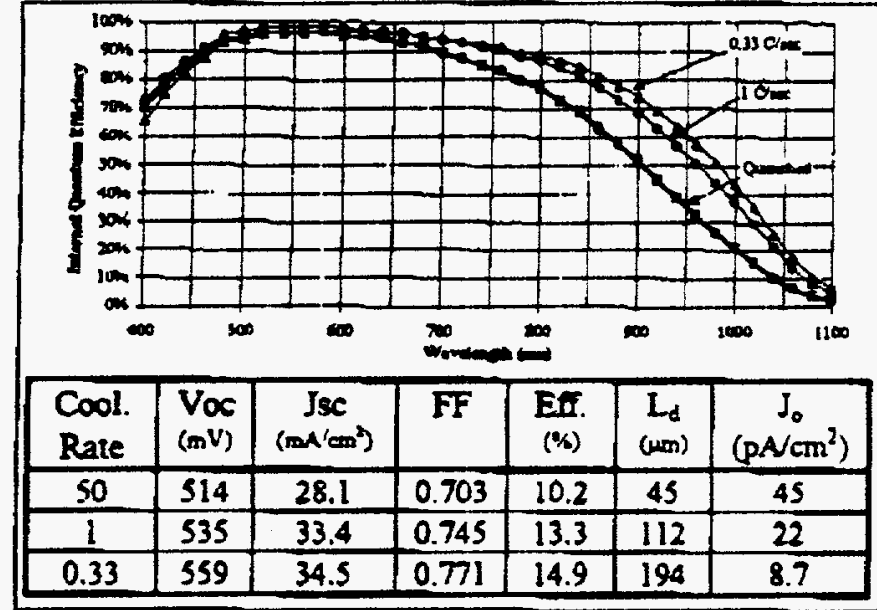

Fie. 7 Effect of RTP cooling rate on 11 R-en dendritic web Si wolv cell performence. Ligtred I.V measured al SNL.

$0.33^{\circ} \mathrm{C} / \mathrm{sec}$. Substantial improvement in the long wavelength IQE response (fig. 7) is attributed to bulk diffusion length enhancement with slower cooling rates. Controlling the cooling rate to $0.33^{\circ} \mathrm{C} / \mathrm{sec}$ achieved a factor of 4 improvement in diffusion length and a factor of $S$ decrease in $J_{0}$. The fact that the bulk diffusion length eahancement is accompanied by an improvernent in $J_{0}$. suggests that $J_{o b}$ is the dominating component of the total $J_{0}=J_{0 t}+J_{0 b}$ and that recombination in the bese is the efficiency-limiting mechanigm for DW cells.

The effect of RTP cooling rates on different materials reveals a more complex phenomenon The effect is highly material and base resistivity specific. For example, in contrast to $\mathrm{DW}$, cells fabricated an FZ showed litrle or no improvement in $\eta_{\mathrm{b}}$. Unlike FZ, DW contains point defects and dislocations; consequently, vacancies, silicon self-interstitials, and possibly impurity atorns such as oxygen may be quenched into electrically active sites upon rapid cool down. Also, the high base doping of $-10^{17} \mathrm{~cm}^{-3}$ in the $0.2 \Omega-\mathrm{cm}$ FZ base masks the impact of quenching due to two reasons. First, quenching may not influence the lifetime of heavily doped materials as much because of the low staring lifetime associeted with dopanirelated complexes. Secandly, these low-resistivity cells generally are more enitrer $\left(J_{o c}\right)$ controlled so that small churges in $\tau_{b}$, which affect $J_{o b}$, do not alter the total $J_{0}$. In fact, the longer annealing times associated with the slower cooling rates hurt the short wavelength response of FZ cells due to excessive heavy doping effects in the emitter. Preliminary results of slow-cooling on $0.8 \Omega-\mathrm{cm} \mathrm{Cz}$ and ma-Si exhibit the similar competition between $\tau_{b}$ enhancement and the undesirable increase in $J_{u s}$. Proper optimization of RTP cooling rates thus requires tuning both the $\tau_{0}$ and $J_{0}$ for maximum efficiency.

\section{CONCLUSIONS}

By developing an RirP temperaturetime cycle consisting of an in-siru anneal for simultaneous tront and back diffusion with suitsble $x_{3}$ and $\mathrm{J}_{0}$, silicon solar cell efficiencies of $-17 \%$ and diffusion lengths $>200 \mu \mathrm{m}$ have been achieved on F2 without any furnace treatnent. Use of low temperature
PECVD SiN/SiO 2 coating further speeds up the process in addition to providing bulk defect and surface pessivation in conjunction with excellent antireflection properties. High cell efficiencies on $\mathrm{Cz}$, dendritic web, and multictystalline demonstrate the competitiveness of RTP as an altemative to furnace processing.

The understanding of the effect of RIP cooling rates has ben impored. For exaitier influenced cells, slower cooling rates may offer betrer lifetimes; but, a penalty in terms of $\mathrm{J}$, may ensue. Therefore, to design cells compatible with high efficiency, a proper optimizntion of the cooling rate is necessary in order to simultaneously enhance the lifetime AND suppress the increase of $J_{\text {s. }}$. Eminter etch-back is one technique that can rectuce $J_{0}$ without sacrificing bulk lifetime [16]. Research is underway to ircorporate costreffective techniques for surface texturing and screen printing to make the RTP/PECVD lechnique more attractive for lowasost highefficiency cells.

\section{REFERRNCES}

(1) C. Chen, P. Sunk J. Sulumi. A Rohatg. IEEE Trans, on Electron Devices 41, 1993, p. 1161.

[2] A Usami, M. Twnokne, T. Wade, Y, lroue. S. Shimada, N. Nuknzawe, Y. Meade, in 18 ih E.C. PV Solar EnergyConf., 1985. Pp. $1078-1083$.

(3) A Usami, M. Ando. M. Trunckene, K. Yumarnoto, T. Wada, Y. lnowe, in 18th E.C. PV Solar Energy Conf.. 1985, pp. 797-803.

[4] R. Campbell. D Meier, J. Electrochem. Soc. 133, 1986. 2210.

[S] B. Harizi, $\Lambda$ Sleovi, J. C. Muller, P. Siffer, in /Neh E.C. PV'Solar Energy Conf., 1992, p. 420.

[6] B. Hartiti A Stroui, J. C. Muller. P. Siffer in Proc. 23 rd LEEE PISC (IEEE, Louirville, 1993), p.224.

[7] R. Schindler, I. Reic, B. Wigner. A Eyer, I. Lautenschleger, C. Scherer, W. Wurs, in Proc. 23rd IEEE PVSC AEEE, Lovitville, 1993), pp. 162-166.

[8] S. Sivoththemar, B. Hartiti, J. Nijs, A Barhdadi, M. Rodot J Mulle, W. Laureys. D. Sani, in 12zh E.C. PV Solar Entrgy Conf., 1994.

[9] O. Bemini, L. Corrers and C. Donolato. "Defects introduced in silicon wufers during rapid isorhermal armealing: Thermoelartic and thermoplastic effect, "J. Appl, Phys. S6. 1984, pp. 2922-2929.

[10] A Rohargi, 2. Chen, P. Doati. T. Pham, and D. Ruby. "Highefficiency tilican solar celle by rapid thermal processing "Appt Phys. Let., 65, 1994. pp. 2087.2089.

[11] B. Hertini, A Slaovi, J. Mulle, and P. Siffer, "Large diffusion length enhancernent in silioon by rapid thermal codiffusion of phosphorus and Auminum "Appl. Phys. Ler, 63, 1993, p. 1249.

(12) B. Hartit, A Slaoui, J. Muller. R. Stuck and P. Sirter, "Phosphorus, diffusion into siliom from a spin-on source uring rapid thermal processing" J. Appl. Phys., 71. 1992. pp. 5474-5478.

[13] A Poggi, E Suti M. Bumiri and M Carroes "Rapid thermal annealing of p-ype silicon" J. Electrochem Soc., 141. 1994. pp. 754-758.

[14] DOE Annual Repon. Sandia National Labaranories Subcontract No. AA-1638, 1993-1994.

[15] W. Eichamener, V. Quat, and P. Siffer, "On the origin of rapid thermal process induced recombination cerrens in silicon," J. Appl. Phys. 66, 1989, pp. 3857.3865.

[16] B. Haniu. J. Muller, and P. Siffer, IFEE Trans. Flectran Devices, 39, 1992. p. 96.

[17] A Rohergi, 8. Rai-Choudtury, in Silicon Processing. ASTM STP 804. D. C. Gupla, Ed, American Sociaty for Testing and Miterials. 1983, p. 389. 